\title{
Factors of variation influencing production level, SCC and basic milk composition in dairy goats
}

\author{
J. Olechnowicz ${ }^{1,3}$ and Z. Sobek ${ }^{2}$ \\ The August Cieszkowski Agricultural University of Poznan', \\ ${ }^{1}$ Department of Veterinary Medicine \\ Wojska Polskiego 52, 61-625 Poznań, Poland \\ ${ }^{2}$ Department of Genetics and Animal Breeding \\ Wotyńska 33, 60-637 Poznań, Poland
}

(Received 15 March 2007; revised version 15 October 2007; accepted 15 January 2008)

\begin{abstract}
Milk yield in goats was influenced by environmental conditions connected with the calendar year. Daily milk production was observed to decrease with progressing lactation, while an increase was observed in SCC, as well as percentage fat and protein contents, while the lactose content in milk decreased. No significant influence was found of birth type, number of kids born or reared on the qualitative and quantitative parameters of milk yield and lactation duration. Goats in their fifth and further lactations produced over $15 \%$ milk less compared with figures recorded in a mediumsized flock (248.9 and $2942.3 \mathrm{ml}$, respectively). Goat milk contained almost $67 \%$ more somatic cells ( $\log 6.099$ and $\log 5.877$, i.e. $1260 \times 10^{3}$ and $755 \times 10^{3}$ cells $\left./ \mathrm{ml}\right)$.
\end{abstract}

KEY WORDS: goat, milk, SCC

\section{INTRODUCTION}

In Poland the average yearly milk production of nearly 9000 goats examined in the years 1983 - 2000 reached $570.4 \mathrm{~kg}$ of milk per animal, with $3.52 \%$ mean fat and $2.93 \%$ mean protein contents (Bagnicka et al., 2002). The level of milk production depends on the breed (Prasad and Sengar, 2002).

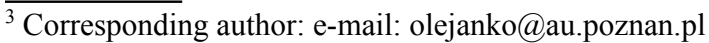


Some reports state that the breed of goats also has an effect on the quality of produced cheese, its sensory value and fatty acid concentration (Tripaldi et al., 1998; Pizzillo et al., 2005). In contrast, other authors have indicated that there was no significant effect of breed on cheese composition, sensory scores, and fatty acid concentrations except for that of oleic acid (Soryal et al., 2005). The number of lactations had a significant effect on the volume of goat milk production and composition (Browning et al., 1995; Crepaldi et al., 1999; Goonewardene et al., 1999; Kominakis et al., 2000; Prasad and Sengar, 2002), the same effect being found for the stage of lactation (Zeng and Escobar, 1995; Prasad and Sengar, 2002). The yield in cheese making was higher when milk from the last stage of lactation was used in comparison with production levels for cheeses produced from midlactation milk (Soryal et al., 2005). The size of production and the percentage content of fat, proteins and lactose are also influenced by the goats' kidding season (Browning et al., 1995; Crepaldi et al., 1999; Prasad and Sengar, 2002), as well as the number of kids born and weaned (Browning et al., 1995; Macciota et al., 2005) and the birth type of goats (Goonewardene et al., 1999). Milk production and composition vary due to external environmental factors such as calendar year (Browning et al., 1995; Crepaldi et al., 1999) or system of kid rearing (Peris et al., 1997). Somatic cell counts (SCC) in goat milk increase with progressing lactation (Wilson et al., 1995) and a seasonal increase in this parameter may be observed in the period from April to September (Zeng and Escobar, 1996).

The objective of the present study was to determine the effect of selected factors (calendar year, successive lactation and stage of lactation, type of birth, as well as the number of kids born and weaned) on the size of production, SCC, as well as basic composition of milk (fat, protein and lactose content) in Polish White Improved goats.

\section{MATERIAL AND METHODS}

The investigations were carried out at the Złotniki Experimental Station belonging to the Agricultural University of Poznań. Polish White Improved goats were analysed in the study. Goats with clinically healthy udders, after weaning of kids (73+/-9d.), were selected for machine milking from May to November. The number of studied goats is given in Table 1 .

Table 1. Number of goats investigated in respective years and months of machine milking

\begin{tabular}{|c|c|c|c|c|c|c|c|}
\hline \multirow{2}{*}{ Calendar year } & \multicolumn{6}{|c|}{ Month of machine milking } & \multirow{2}{*}{ Total } \\
\hline & 1 & 2 & 3 & 4 & 5 & 6 & \\
\hline 2001 & 23 & 22 & 20 & 19 & 15 & 15 & 114 \\
\hline 2002 & 11 & 19 & 19 & 16 & 15 & 13 & 93 \\
\hline $2001-2002$ & 34 & 41 & 39 & 35 & 30 & 28 & 207 \\
\hline
\end{tabular}


Goats were milked in 11 stands of a milking parlour (Westfallen). The technical control of the milking appliance was conducted annually. Both the frequency of pulsation and the value of pulsator coefficients were measured applying a MilkoTest 2000 electronic pulsograph. Milking was conducted at a vacuum level of $41 \mathrm{kPa}$, pulsation rate of 69.9 to $76.7 \mathrm{pulses} / \mathrm{min}$ and pulsation ratio of $60 \pm 5 \%$. During lactation goats were fed green lucerne forage $(7-8 \mathrm{~kg})$, concentrate $(0.8$ $\mathrm{kg})$, meadow hay $(0.3-0.5 \mathrm{~kg})$ and fodder straw $(0.4 \mathrm{~kg})$. Each year 6 milk recordings were performed to determine morning and evening milk yields (in $\mathrm{ml}$ ). At each recording before morning milking after forestripping, washing and drying of teats, approx. $50 \mathrm{ml}$ of milk (preserved with CC preparation) were collected from each half of the udders. The CC preparation ensures the maintenance of chemical parameters of milk samples for 30 days at room temperature $(0.25 \mathrm{~g} / 50 \mathrm{ml}$ milk).

Milk samples were analysed at the Laboratory of Milk Evaluation in Krotoszyn (Poland). Fat, protein and lactose contents in milk were determined with a MilkoScan device, while a Fossomatic apparatus was used to evaluate SCC in milk. Somatic cell count values were transformed to a common logarithm (log SCC) in order to obtain a distribution close to normal (Ali and Shook, 1980). The obtained numerical results were statistically analysed by multivariate analysis of variance (SAS, 2005). The following linear models were applied in the calculations:

Model 1:

$$
y_{i j k l m n o}=\mu+A_{i}+B_{i j}+C_{i j k}+D_{i j k l}+E_{i j k l m}+F_{n}+e_{i j k l m n o}
$$

where: $y_{i j k l m n o}$ - test day milk production $(\mathrm{ml})$, days in milk, $\mu$ - grand mean, $A_{i}$ - the effect of the $\mathrm{i}$-th calendar year $(\mathrm{i}=1,2), B_{i j}$ - the effect of the $\mathrm{j}$-th month of machine milking $(j=1,2,3,4,5,6), C_{i j k}$ - the effect in the $i$-th year of the $\mathrm{k}$-th birth type $(\mathrm{k}=1,2,3,4), \mathrm{D}_{\mathrm{ijkl}}$ - effect of the 1 -th number of kids born $(1=1,2$, $3,4,5), E_{i j k l m}$ - effect of the number of the $\mathrm{m}$-th weaned kids $(\mathrm{m}=0,1,2,3,4), F_{n}$ - the effect of the $\mathrm{n}$-th number of lactation $\left(\mathrm{n}=2,3,4,5\right.$ and more than 5), $e_{i j k l m n o}$ - the effect of random error.

Model 2:

$$
y_{i j k l m n o p}=\mu+A_{i}+B_{i j}+C_{i j k}+D_{i j k l}+E_{i j k l m}+F_{n}+G_{o}+e_{i j k l m n o p}
$$

where: $\mathrm{y}_{\mathrm{ijklmnop}}$ - SCC (log SCC), fat, protein and lactose contents in milk (\%), $A_{i}$ - the effect of the $\mathrm{i}$-th calendar year $(\mathrm{i}=1,2), B_{i j}$ - the effect of the $\mathrm{j}$-th month of machine milking $(j=1,2,3,4,5,6), C_{i j k}$ - the effect in the $\mathrm{i}$-th year of the k-th birth type $(\mathrm{k}=1,2,3,4), D_{i j k l}$ - effect of the 1 -th number of kids born $(1=1,2,3,4$, 5), $E_{i j k l m}$ - effect of the number of the $\mathrm{m}$-th weaned kids $(\mathrm{m}=0,1,2,3,4), F_{n}$ - the effect of the $\mathrm{n}$-th number of lactation $(\mathrm{n}=2,3,4,5$ and more than 5$), G_{o}$ - the effect of o-th half of udder $(\mathrm{o}=1,2), e_{i j k l m n o p}-$ the effect of random error. All effects (except the error term) are treated as fixed. 
The general statistical analysis of data (modelled by models 1 and 2) was based on testing general hypotheses concerning the effects of the above models by the F-Fisher-Snedecor test. After rejecting the main hypotheses, further inference was based on comparisons of all possible effects. Overall inference was performed at two significance levels, namely $\alpha=0.05$ and $\alpha=0.01$.

\section{RESULTS AND DISCUSSION}

Phenotypic means, standard deviations, minimums and maximums for milk yield traits of goats are given in Table 2. Daily milk yields and somatic cell

Table 2. Phenotypic means, standard deviations, minimums and maximums for milk yield traits of goats

\begin{tabular}{lrrrrc}
\hline Parameters & Mean & SD & $\begin{array}{c}\text { Observa- } \\
\text { tion } \mathrm{n}\end{array}$ & Minimum & Maximum \\
\hline Milk production, ml & 2942.32 & 937.569 & 207 & 800 & 5000 \\
Days in milk & 203.23 & 40.542 & 207 & 53 & 243 \\
Number of born kids & 2.15 & 0.844 & 42 & 1 & 5 \\
Number of weaned kids & 1.85 & 0.942 & 42 & 0 & 4 \\
Log SCC & 5.877 & 0.6368 & 414 & 3.449 & 7.264 \\
Fat content in milk, \% & 3.04 & 0.905 & 414 & 1.14 & 5.96 \\
Protein content in milk, \% & 3.01 & 0.594 & 414 & 1.96 & 6.63 \\
Lactose content in milk, \% & 4.25 & 0.746 & 414 & 0.20 & 9.91 \\
\hline
\end{tabular}

counts in goat milk (log SCC) as well as content of basic milk constituents are characterized by considerable variation between individual goats. As reported by Bernacka (2006), Colour Improved goats also exhibit large variation in terms of somatic cell counts in milk (min. 10, max. 10261 thousand cell/ml) and percentages of fat, protein and lactose $(4.60 \pm 1.88 ; 3.26 \pm 0.89$ and $4.43 \pm 0.30$, respectively). A similar variation of daily milk yield and somatic cell counts, as well as contents of fat, protein and lactose in milk was found in Alpine goats (Zeng and Escobar, 1995; Zeng et al., 1997) and Murciano-Granadina goats (López et al., 1999). Ciappesoni et al. (2004) in 6234 Czech White Shorthaired goats analysed in the years 1992-2002 also reported a large variation in daily milk yield $(3.09 \pm 1.30 \mathrm{~kg})$ and fat and protein contents in milk $(3.72 \pm 0.99$ and $2.84 \pm 0.47 \%$, respectively). A lower variation in milk constituents was recorded in the Polish population of milk goats (Bagnicka et al., 2002) and in Barbari goats and crosses with Jamunapari, Bental and Black Bengal breeds (Prasad and Sengar, 2002).

Goats of this breed were characterized by a higher average daily production of milk than goats of the Alpine breed (Zeng and Escobar, 1996; Zeng et al., 1997), 
Sarda goats (Macciota et al., 2005), Black Bengal goats (Hossain et al., 2004) and their hybrids with the Jamunapari and Bengal breeds (Prasad and Sengar, 2002). Contents of fat, protein and lactose in analysed goat milk, as well as SCC levels were found to be at approximately the same level as in milk of other breeds (Zeng and Escobar, 1995; Peris et al., 1997; Zeng et al., 1997; Goonewardene et al., 1999; Das et al., 2000; Soryal et al., 2005 ).

Table 3. The effect of selected factors on level of goat milk production

\begin{tabular}{|c|c|c|c|}
\hline Factor & $\begin{array}{c}\text { Observation } \\
\mathrm{n}\end{array}$ & $\begin{array}{l}\text { Daily milk production } \\
\mathrm{ml}\end{array}$ & Dairy in milk \\
\hline Calendar year & & $* *$ & $* *$ \\
\hline 2001 & 114 & 3138.25 & 220.04 \\
\hline 2002 & 93 & 2702.15 & 182.61 \\
\hline Month of milking & & ** & \\
\hline 1 & 34 & $3275.00^{\mathrm{CD}}$ & \\
\hline 2 & 41 & $3058.50^{\mathrm{EF}}$ & \\
\hline 3 & 39 & $3287.40^{\mathrm{AB}}$ & \\
\hline 4 & 35 & $2968.60^{\mathrm{G}}$ & \\
\hline 5 & 30 & $2596.70^{\mathrm{ACE}}$ & \\
\hline 6 & 28 & $2225.00^{\mathrm{BDFG}}$ & \\
\hline Birth type & & $* *$ & NS \\
\hline 1 & 9 & 2922.22 & 224.00 \\
\hline 2 & 153 & $2991.90^{\mathrm{B}}$ & 204.76 \\
\hline 3 & 36 & $2627.78^{\mathrm{AB}}$ & 195.08 \\
\hline 4 & 9 & $3377.78^{\mathrm{A}}$ & 189.00 \\
\hline Number of kids at birth & & NS & $* *$ \\
\hline 1 & 40 & 3204.00 & $223.95^{\mathrm{DE}}$ \\
\hline 2 & 117 & 2864.53 & $199.14^{\mathrm{ADF}}$ \\
\hline 3 & 33 & 2892.42 & $189.76^{\mathrm{CEF}}$ \\
\hline 4 & 12 & 3000.00 & $243.00^{\mathrm{ABC}}$ \\
\hline 5 & 5 & 2860.00 & $186.00^{\mathrm{B}}$ \\
\hline Number of weaned kids & & ** & ** \\
\hline 0 & 12 & $3691.67^{\mathrm{ABC}}$ & 214.50 \\
\hline 1 & 62 & $3000.16^{\mathrm{A}}$ & $221.52^{\mathrm{CD}}$ \\
\hline 2 & 88 & $2789.77^{\mathrm{C}}$ & $191.82^{\mathrm{AC}}$ \\
\hline 3 & 39 & $2930.26^{\mathrm{B}}$ & $190.45^{\mathrm{BD}}$ \\
\hline 4 & 6 & 2900.00 & $243.00^{\mathrm{AB}}$ \\
\hline Number of lactations & & $* *$ & $* *$ \\
\hline 2 & 13 & $2755.38^{\mathrm{B}}$ & $197.54^{\mathrm{B}}$ \\
\hline 3 & 73 & $3387.53^{\mathrm{ABC}}$ & $225.22^{\mathrm{ABC}}$ \\
\hline 4 & 48 & $3014.58^{\mathrm{AD}}$ & $179.44^{\mathrm{CD}}$ \\
\hline further 5 and & 73 & $2482.88^{\mathrm{CD}}$ & $197.89^{\mathrm{AD}}$ \\
\hline
\end{tabular}

NS - not significant, ${ }^{* *} \mathrm{P}<0.01,{ }^{\mathrm{A}-\mathrm{G}}$ - values within each column and each factor with the same letters differ significantly $(\mathrm{P}<0.01)$ 
Table 4. The effect of selected factors on somatic cell counts (log SCC) and fat, protein and lactose contents (\%) in goat milk

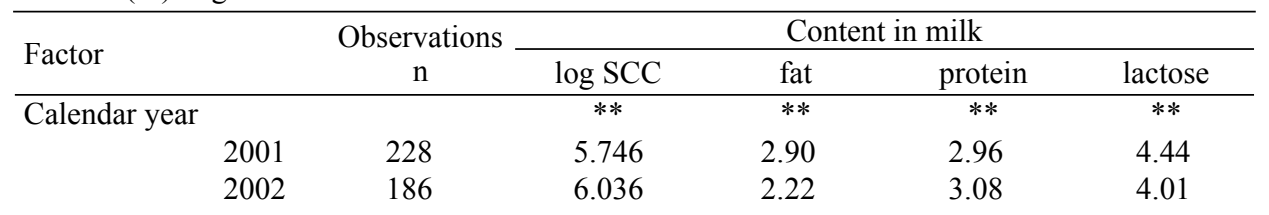

Month of milking

$\begin{array}{ll}1 & 68 \\ 2 & 82 \\ 3 & 78 \\ 4 & 70 \\ 5 & 60 \\ 6 & 56\end{array}$

Birth type

$\begin{array}{rr}1 & 18 \\ 2 & 306 \\ 3 & 72 \\ 4 & 18\end{array}$

Number of born kids

$\begin{array}{rr}1 & 80 \\ 2 & 234 \\ 3 & 66 \\ 4 & 24 \\ 5 & 10\end{array}$

Number of weaned kids

$\begin{array}{rr}0 & 24 \\ 1 & 124 \\ 2 & 176 \\ 3 & 78 \\ 4 & 12\end{array}$

Number of lactations

$\begin{array}{lr}2 & 26 \\ 3 & 146 \\ 4 & 96 \\ 5 \text { and } & 146 \\ \quad \text { further } & \end{array}$

Udder halves

\begin{tabular}{|c|c|c|c|c|c|}
\hline & & NS & NS & NS & NS \\
\hline left & 207 & 5.884 & 3.01 & 2.90 & 4.33 \\
\hline right & 207 & 5.919 & 3.07 & 2.98 & 4.16 \\
\hline
\end{tabular}

NS - not significant, ${ }^{* *} \mathrm{P}<0.01,{ }^{\mathrm{A}-\mathrm{K}}$ values within each column and each factor with the same letters differ significantly $(\mathrm{P}<0.01)$ 
Tables 3 and 4 present results of the analysis of variance taking into consideration factors influencing the level of milk production, days in milk, SCC (log SCC) and the basic composition of milk. The majority of factors considered in the analysis significantly influenced $(\mathrm{P}<0.01)$ daily milk production, days in milk, SCC and the basic composition of milk.

Daily milk production, days in milk, somatic cell counts as well as basic composition of milk were significantly different in the two years of the study. In the first year of investigation, higher daily milk production was recorded and milk in that year was characterized by significantly lower SCC, higher fat and lactose contents and a lower protein content. A higher number of days in milk was also recorded in the first year of the study. The calendar year as well as the month of kidding and the age of Damascus goats in Cyprus were reported to influence milk production (Mavrogenis et al., 1984). However, the effect of the year was not confirmed for fat and protein contents in milk, as well as the length of lactation in Nubian goats (Goonewardene et al., 1999).

During the months of machine milking (except month 3) a decrease in daily milk production was observed. Somatic cell count was observed to increase with a decrease of lactose content in milk $(\mathrm{P}<0.01)$. The decrease of goat milk yield with progressing lactation and milk composition changes ascribed to it are in agreement with the results of investigations carried out by other authors (Peris et al., 1997; Prasad and Sengar, 2002; Soryal et al., 2005). In Alpine goats the calculated values of coefficients of phenotypic correlations between somatic cell counts and fat and protein contents in milk were positive, amounting to $0.41(\mathrm{P}<0.01)$ and $0.23(\mathrm{P}<0.05)$, respectively. However, they were negative between somatic cells counts and lactose content in milk, the values being -0.41 and -0.46 , respectively $(\mathrm{P}<0.001$; Zeng and Escobar, 1995). In correlation with increasing somatic cells counts in milk $\left(<750,750-1750\right.$ and $>1750 \times 10^{3}$ cells $\left./ \mathrm{ml}\right)$ a significant increase of protein content in milk, amounting to 28.6, 29.1 and 30.1 $\mathrm{g} / \mathrm{kg}$ of milk, was observed for the respective somatic cell levels (Baudry et al., 1997).

Although birth type of goats differentiated daily milk production, no significant increase of milk yield was found for goats coming from multiple births in comparison with goats from single births. A decrease in protein content was recorded in milk of goats from multiple births. After the second kidding, Black Bengal goats from triple births produced more milk per lactation $(25.19 \mathrm{~kg})$ than those coming from single births (19.22 and $20.84 \mathrm{~kg}$, respectively; Hossain et al., 2004). Nubian goats coming from multiple births produced significantly more milk in 250 and 305 days (80.6 and $972.1 \mathrm{~kg}$, respectively) in comparison with goats from single births (664.6 and $800.9 \mathrm{~kg}$, respectively). Milk produced by goats from single and multiple births did not differ significantly in terms of either fat or protein contents (Goonewardene et al., 1999). 
Litter size did not influence daily milk yield; similarly, the number of weaned kids did not affect production levels, only the goats that had no offspring showed higher milk yields compared with those nursing one, two or three kids $(\mathrm{P}<0.01)$. No significant effect was confirmed of the number of born and weaned kids on lactation length. In goats rearing a high number of kids, higher milk protein and lactose contents were recorded. At the same time, in those goats an upward trend was recorded for somatic cell counts $(\log \mathrm{SCC})$. The results reported by other authors, however, indicate a significant effect on milk yield of the number of kids born and weaned (Browning et al., 1995; Crepaldi et al., 1999; Macciota et al., 2005).

Goats in the third lactation produced more milk daily than goats in their second, fourth as well as fifth and further lactations $(\mathrm{P}<0.01)$. Similarly, higher milk yields were recorded for goats in their fourth lactation than for goats in their fifth and further lactations. The third lactation was longer than the other ones. The lower milk yield in further lactations was connected with a higher SCC content, as well as a reduced lactose content in milk. Similarly, in Nubian goats the following lactation did not have an effect on milk yield in a 305-day lactation, fat content, or the length of lactation (Goonewardene et al., 1999). Barbari goats and their crosses with Jamunapari, Beetal and Black Bengal breeds only in the second and further lactations produced more milk daily than goats in their first lactation (Prasad and Sengar, 2002). There was a clear reduction of the quantity of milk produced by Alpine goats, which was recorded starting from the fifth and further lactations, the same trend being observed for fat level (Browning et al., 1995).

Somatic cell counts as well as fat, protein and lactose contents recorded for the left and right udder-halves were comparable.

\section{CONCLUSIONS}

The level of milk yield is influenced by environmental conditions connected with the calendar year. A decrease in the daily milk production with progressing lactation and an increase of somatic cell counts as well as fat and protein contents, and a decrease of lactose content in milk were observed. No significant effect of the type of birth of goats, as well as the number of born and weaned kids on both quantitative and qualitative parameters of goat milk yield and the length of lactation was confirmed in this study.

Goats in their fifth and further lactations produce over 15\% less milk in comparison with the flock average and the milk contains nearly $67 \%$ more somatic cells. 


\section{REFERENCES}

Ali A.K.A., Shook G.E., 1980. An optimum transformation for somatic cell concentration in milk. J. Dairy Sci. 63, 487-490

Bagnicka E., Łukaszewicz M., Distl O., Hamann H., 2002. Genetic and environmental trends in Polish dairy goats. Anim. Sci. Pap. Rep. 20, 195-202

Baudry C.R., de Cremoux R., Chartier C., Perrin G., 1997. Incidence de la concentration cellulaire du lait de chèvre sur sa production et sa composition. Vet. Res. 28, 277-286

Bernacka H., 2006. Cytological quality of goat milk on the basis of the somatic cell count. J. Cent. Eur. Agr. 7, 773-778

Browning Jr. R., Leite-Browning M.L., Sahlu T., 1995. Factors affecting standardized milk and fat yields in Alpine goats. Small Ruminant Res. 18, 173-178

Ciappesoni G., Přibyl J., Milerski M., Mareš V., 2004. Factors affecting goat milk yield and its composition. Czech J. Anim. Sci. 49, 465-473

Crepaldi P., Corti M., Cicogna M., 1999. Factors affecting milk production and prolificacy of Alpine goats in Lombardy (Italy). Small Ruminant Res. 32, 83-88

Das M., Singh M., 2000. Variation in blood leucocytes, somatic cell count, yield and composition of milk of crossbred goats. Small Ruminant Res. 35, 169-174

Goonewardene L.A., Okinea E., Patrick N., Scheer H.D., 1999. The relationship between multiple birth and milk yields in non-suckled intensively managed dairy goats. Small Ruminant Res. 32, 181-185

Hossain S.M.J., Alam M.R., Sultana N., Amin M.R., Rashid M.M., 2004. Milk Production from Indigenous Black Bengal Goat in Bangladesh. J. Biol. Sci. 4, 262- 265

Kominakis A., Rogdakis E., Vasiloudis Ch., Liaskos O., 2000. Genetic and environmental sources of variation of milk yield of Skopelos dairy goats. Small Ruminant Res. 36, 1-5

López M.B., Jordán M.J., Granados M.V., Fernández J.C., Castillo M., Laencina J., 1999. Viscosity changes during rennet coagulation of Murciano-Granadina goat milk. Int. J. Dairy Technol. 52, 102-106

Macciota N.P.P., Fresi P., Usai G., Cappio-Borlino A., 2005. Lactation curves of Sarda breed goats estimated with test day models. J. Dairy Res. 72, 470-475

Mavrogenis A.P., Constantinou A., Louca A., 1984. Environmental and genetic causes of variation in production traits of Damascus goats. 2. Goat productivity. Anim. Prod. 38, 99-104

Peris S., Caja G., Such X., Casalas R., Ferret A., Torre C., 1997. Influence of kid rearing systems on milk composition and yield of Murciano-Granadina dairy goats. J. Dairy Sci. 80, 3249-3255

Pizzillo M., Claps S., Cifuni G.F., Fedele V., Rubino R., 2005. Effect of goat breed on the sensory, chemical and nutritional characteristics of ricotta cheese. Livest. Prod. Sci. 94, 33-40

Prasad H., Sengar O.P.S., 2002. Milk yield and composition of the Barbari goat breed and its crosses with Jamunapari, Beetal and Black Bengal. Small Ruminant Res. 45, 79-83

SAS, 2005. Version 9.1. SAS Institute Inc. Cary, NC

Soryal K., Beyene F.A., Zeng S., Bah B., Tesfai K., 2005. Effect of goat breed and milk composition on yield, sensory quality, fatty acid concentration of soft cheese during lactation. Small Ruminant Res. 58, 275-281

Tripaldi C., Martillotti F., Terramoccia S., 1998. Content of taurine and other free amino acids in milk of goats bred in Italy. Small Ruminant Res. 30, 127-136

Wilson D.J., Keith N.S., Sears P.M., 1995. Effects of stage of lactation, production, parity and season on somatic cell counts in infected and uninfected dairy goats. Small Ruminant Res. 16, 165-169

Zeng S.S., Escobar E.N., 1995. Effect of parity and milk production on somatic cell count, standard plate count and composition of goat milk. Small Ruminant Res. 17, 269-274

Zeng S.S., Escobar E.N., 1996. Effect of breed and milking method on somatic cell count, standard plate count and composition of goat milk. Small Ruminant Res. 19, 169-175

Zeng S.S., Escobar E.N., Popham T., 1997. Daily variations in somatic cell count, composition, and production of Alpine goat milk. Small Ruminant Res. 26, 253-260 